\title{
Implicatures in Political Discourse on Indonesia Lawyers Club Show
}

\author{
MUTIA EL KHAIRAT \\ English Department, State Polytechnic of Padang, Limau Manis, Padang, 2500, Indonesia \\ E-mail: mutiaelkhairatpnp@gmail.com
}

\begin{abstract}
Implicature in political discourse is one of interesting problem to be studied in linguistics. Sometimes, many politicians use sentences which imply something different than the literal meaning for certain political purposes. Mass media is one of intercession between political doer and people, such as a talk show or dialogue of politics on television. Indonesia Lawyers Club is one of dialogue in television, which discuss about political issues in Indonesia. This article aimed at describing and explaining forms and kinds of implicature used in political discourse by using implicature theory from Grice (1975) and Gazdar (1979). The method use in collecting the data is observational method and technique of Non Participant Observation (NPO) followed by recording and note taking technique. Furthermore, this study uses referential and pragmatic identity method in analyzing data. It is a descriptive research in which using a qualitative approach. The data of the research are taken from utterances as found in the political dialogue entitled Indonesia Lawyers Club, as TV programs. The result of research shows that implicature has found and used in political discourse in Indonesia Lawyers Club by breaking the cooperation principle in declarative and negative form, while interogative is not found in this show. Besides, the use of implicature also found in the kinds of conventional implicature, generalized conversational and particularized conventional implicature, and scalar implicature. Furthermore, the meaning of implicature consists of criticism, teasing, obscurity of meaning, image projection, agree, disagree, and euphemism. Pragmatics functions in implicature consist of assertive, directive, expressive and commisive. Finally, the value in implicature consists of political value, those are self-image of ideology, power, aversion, democracy, and protection, and morality value.
\end{abstract}

Keywords - Implicature; Political Discourse; Indonesia Lawyers Club

\section{INTRODUCTION}

The use of implicature in political field becomes an interesting phenomenon to be discussed as it relates to political language. Political language is the language that is used as political tools, such as languages of slogans or propaganda, government official languages in speech or language which is used in the speeches of party leaders, and the writings about political themes that contains the intention to achieve certain goals (Darma, 2009, p. 91). According to Beard (2000) political language is related to power, for instance the language that is used by politicians who want power, politicians who want to carry out their power and politicians who want to maintain their power.

Politicians use implicatures for political interests such as, campaigns, political speeches, and so forth. Implicature is considered as an effective way to convey the intention and purpose of the speaker without saying it explicitly. Furthermore, political exhibitors not only use language to express their political purposes and goals to the public, but also to hide certain things for the sake of political interests. Therefore, implicatures become one of the politicians speaking strategy when they speak in front of public. One example is the presidential candidate campaign ads which broadcasted on television and published in the print media. This campaign advertisement used short and simple slogan to make it easier to remember that is "Lanjutkan!" which means continue. The catchy campaign slogan will attract the attention of people and it also can influence people's decision to vote one of the presidential candidates. Nevertheless, the meaning of this slogan can be elaborated base on its context, for example 'Vote me in the upcoming elections' In addition, the slogan also implies the desire to continue the authority as president 
because that person has served as president in the previous period.

Based on the example above, it can be concluded that the ultimate goal of political language is not only to construct the existing realities but also bring single or a number of interests. In the world of journalism, this is known as framing which the end result is known as a discourse (Sumardjo, 2010, p. 882). Such a strategy is also applied in politicians speech utterances because the packaging is not only to convey their purpose or mind, but there are also interests to be delivered to the public. Therefore, the politician utterance is a reality that has been constructed in the form of meaningful discourse which is called as political discourse

Wilson as cited in Schiffrin (2003, p. 398) stated that the limits of political discourse focused on the problems of the formal or informal political context and political exhibitors or politicians, political government institutions, the public media, political supporters who have functioned in a political environment to achieve political goals. Political targets can be obtained through mass media such as newspapers, radio and television. Television is considered to have more advantages than other media because of it is classified as audio-visual media that can be seen and heard. Therefore, television is not only used as a source of information by the public, but is also used as an intermediary for the politicians to achieve political goals.

Political exhibitors use the opportunity to appear on television to deliver their aims and certain objectives of the public. One way to convey their aims is by attending the dialogue which is created by a television station to discuss emerging political issues. One of the dialogues which has been produced for political discussions on television is Indonesia Lawyers Club that aired on TV One. Indonesia Lawyers Club or hereafter abbreviated as ILC is a dialogue which discuss some issues around the theme of political development, social development, and law enforcement issues related to all aspects of life. The dialogue participants who attended ILC are advocates, Corruption Eradication Commission (KPK), The General Election Commission (KPU), The Constitutional Court (MK), representatives of political parties, elements of the Indonesian National Police (POLRI), prosecutors, and other elements which are related to law enforcement and political atmosphere in Indonesia.

According to Wilson as cited in Schiffrin (2003, p. 400) politicians often want to hide the negative things in certain formulations so that the public cannot see the truth or the case before them. It aims to protect the image of politicians and their group in front of the public so they can get sympathy as expected in political strategy. In that occasion, politicians and those involved in it using implicature to avoid worse undesirable possibilities. It is done to hide the negative things which probably come to people's mind.

Based on these phenomena, implicatures in political discourse on Indonesia Lawyers Club is very interesting to discuss. This paper discusses about "what are the form and type of implicatures in the political discourse on Indonesia Lawyers Club?" By elaborating the problem, it can be revealed that the implicature is one of the strategies which used by politician utterances in mass media, especially television. The main data of this study is the conversation between the host of ILC with its participants and between participants in the dialogue itself. The data were taken from three episodes of ILC show episodes 78, 79, and 80. The assessment is based on the theory of implicature which is stated by Grice (1975) and Gazdar (1979) on the principles of cooperation and types of implicatures. In addition, this study also discusses the meaning, function, as well as the values contained in the implicatures usage.

\section{RESEARCH METHOD}

This study tries to look at the use of implicatures in political discourse on Indonesia Lawyers Club show that examines the form and types of implicature which are used in ILC dialogue by using qualitative research. This research data are taken from the political dialogue show entitled Indonesia Lawyers Club that is aired live on TV One every Tuesday at 19:30 pm. Data analysis was done by using observational methods and techniques of Non-Participant Observation (NPO). It is a method where the writer observed the data whithout involve onto the dialogue. Therefore, the writer listen to the dialogue and let it happen naturally. After that, it was followed by recording and note-taking technique proposed by Sudaryanto (1992). The writer recorded the show 
from television and took a note all utterances which appeared in the show.

Meanwhile, the analysis method used in this research is referential and pragmatic identity method. Referential method is used to analyze utterances that are associated with the data and related to specific referents in the implicature utterances in political discourse. Pragmatic identity methods are used to analyze the meaning behind spoken utterances and conversations that appear in Indonesia Lawyers Club show. The techniques that are used to apply these methods consists of the basic techniques aggregated decisive element which has aggregated power mentally and advanced technique of comparing and relate which consists of equating and differentiating elements of linguistic in obtaining implicatures utterances.

\section{THEORETICAL B ACKGROUND}

\section{A. DEFINITION of IMPLICATURE}

Grice stated that an utterance could imply propositions that are not part of the related utterance, while the implied proposition is called implicature (Wijana, 1996, p. 37). Every form of utterance is usually assumed to have certain intention. The intention of an utterance which is called by Grice (1975, p. 44) as implicatum or something that is implied, and then it is formulated with the term of non-natural non-natural (meaning $\mathrm{nn})$. According to Mulyana (2001, p. 54) the symptoms of that phenomenon are called as implicature relating to the implications or in the study of pragmatics and discourse mean something involved in the conversation.

Implicature includes some theoretical development of the relationship between the expression, the meaning of utterances, the meaning of the speaker, and the implications of an utterance. The term of Implicature is used in linguistics to study the conversation, which means other implications that can be derived from an utterance (Oktavianus, 2006, p. 90). It means, in a conversation which involving the speakers and listeners often contain certain purpose that is different from the use of language. Thus, in the speaker's utterance actually has a hidden purpose behind the use of language structure.

Grice stated that the theory of implicatures is used as a way to explain the meaning of the language which cannot be resolved by the semantic theory. Furthermore, Levinson (1987, p. 97-100) stated that: (1) the theory of implicature can provide a functional explanation of the facts of language which is not covered by the linguistic theory (structural), (2) the theory of implicature gives an explicit explanation about the differences between what was said literally to what is meant by an utterance, while language users also understand it, (3) the theory of implicature can simplify describe different clause semantic relationships and the conjunction, (4) implicature theory can explain the variety of linguistic symptomps literally which appear unrelated or even opposite to each other, but actually they are associated.

Grice (1975, p. 45) distinguished implicatures into two types, they are conventional implicature and conversational implicatures. Conventional implicature consists of implications which derived directly from the meaning of words (something that is listened) instead of the principle of conversation. According to Mulyana (2001, p. 57) non-conventional implicatures are temporary, it means that the meaning is more durable where a lexeme meaning is already "old" so it is generally known. Conversational implicature is illocutionary acts where the pragmatic implications drawn from the principles of conversation. The basic assumption of a conversation is a conversation whose participants follows the principle of cooperation and maxims (Yule, 1996, p. 40). In communication, utterances always present a pragmatic function and in the conversation utterance is implied an intention or other pragmatic function which is called conversational implicatures.

Gazdar (1979, p. 38) then differentiated implicature forms into conversational implicature, generalized conversational implicatures and particularized conversational implicatures. Generalized conversational implicature is an implicature whose presence in the conversation does not require a specific context. Furthermore, particularized conversational implicature is an implicature whose occurrence requires a special context. Usually, conversations that occur between a speaker and listener are included by a special context that is affected by the same background knowledge among participants. Yule (1996) also suggested another type of implicature, that is the 
scalar implicature. In a conversation, sometimes certain information is communicated by choosing a word that expresses a value of scale, such as all, most, many, some, few, always, often, sometimes (Yule, 1996, p. 41). When producing an utterance, the speaker selects a word from the scales above which are considered as the most informative and honest scale (quantity and quality)

\section{B. COOPERATIVE PRINCIPLES}

Grice (1975) explained that basically implicatures related to the general principle in pragmatics. The general principles are the cooperation that is contributed between the speakers and listeners in a conversation. The point is that, between speaker and hearer is expected that there is a cooperation which appropriate with the necessity and the acceptance level of acceptable and agreed meaning. Thus, a number of the implied meaning of the utterance can be understood by the hearer.

In this regard, Grice (1975, p. 45) suggested the principle of cooperation, namely "Make your conversational contribution such as is required, at the stage at the which it occurs, by the accepted purpose or direction of the talk exchange in the which you are engaged" Make your conversations as you want when you talk based on the appropriate objectives conversations or its direction which you are following of. The same cooperative principle consists of four maxims, those are:

1. Maxim of Quantity. This maxim is intended to make the speakers talk as needed and do not need to say something that is not important. In the maxim of quantity a speaker is expected to provide sufficient information, relatively adequate, and as informative as possible. The speakers are also expected not provide information beyond that is required.

2. Maxim of Quality. It is occurred when the speaker does not say anything that is not true and do not say anything that have no proof. In the maxim of quality, the participant is expected to deliver something tangible and factual in the utterance.

3. Maxim of Relevance. This maxim is where the speakers should say something that is useful and relevant. The speaker is expected to say something that has a relationship with the subject.
4. Maxim of Manner. It is intended for the speakers to speak clearly, avoiding vague statements, ambiguity, and speak briefly and wellorganized

\section{MEANING and PRAGMATIC FUNCTION of IMPLICATURE}

Meaning is the intention of the speaker; the influence of language units in the perception, understanding of human behavior or groups of people; relationship, in the sense of equivalence or discordance between languages, or between utterance and all related things (Kridalaksana, 2008, p. 148). Based on that understanding about the meaning, Odgen and Richards (1985) described the basic triangle as follows:

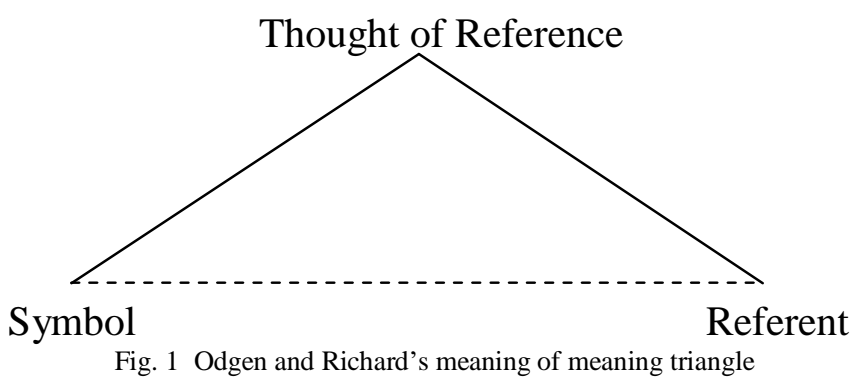

The chart above explains that the idea of a reference presents the specific meaning which is associated with the symbols and references. Meanwhile, there is an indirect relationship between symbols and references because of its arbitrary relationship bound that produce different symbols although the reference is the same.

Meanwhile, pragmatic function is the relationship between language elements with other elements in the context of extensive communication (Kridalaksana, 2008, p. 68). An implication which occurs from an utterance has a pragmatic function because implicatures are related to the context of the communication. Pragmatic functions in implicature utterance arise as a result of violations of cooperation maxims in speech acts between the speakers and the listeners. Therefore, pragmatic function of implicature utterance is related to the function of speech acts. Searle as cited in Trosborg (2002, p. 20-21) characterized the function of speech acts in five, they are:

1. Assertive is a form of utterance that bind the speakers on the truth of propositions which are expressed in the speech 
2.Directive is a form of utterance that is intended by the speakers to create the effect for the listener to take action as he wanted or do nothing

3. Expressive is a form of utterance that aimed at expressing or showing the psychological attitude of the speaker to the particular circumstances

4. Commisive is a form of utterance that is used to express a promise or a particular offering that ties the speaker to do an action in the future

5.Declarative is a form of utterance that connects the contents of utterance and reality.

\section{VALUES and CONTEXT}

According to Kridalaksana (2008, p. 162) value is a functional identity of language element in a system, where in this context language is an unimpeded element of language with its own values which is determined by correlation syntagmatically and paradigmatically. It means generally, value is something valuable, useful, and good in society. Spranger as cited in Mulyana (2004, p. 32) classified values into theoretical values, economical values, aesthetical values, social values, political values, and religious values.

Furthermore, Hymes (1962) related pragmatics studies, especially implicature with a context which consist of eight elements of SPEAKING, they are:

1. Setting refers to the time and place in which interaction takes place

2. Participants include the speaker and the audience, the latter including addressee and any others present

3. Ends refers to both outcome (the assume purpose of an activity or event) and goals (the purpose of the individuals involved)

4. Act sequence is the different part of a communicative event

5. Key is determined by cues that indicate its tone or spirit

6. Instrumental refers to the forms and styles of speech used by participant

7. Norms refer to any socially accepted conventions regarding when people can speak, what kind of things they can say and who they can say it to.

8. Genre is not only used to refer to literary work but also to the kind of communication that is taking place

\section{RESULT AND DISCUSSION}

\section{A. FORM of IMPLICATURES}

The form of implicature of political discourse on ILC was found to appear in the form of a declarative sentence, imperative and interrogative because of the violation of the cooperative principle expressed by Grice. Violation of the cooperative principle consists of a violation against maxim of quantity, maxim of quality, the maxim of relevance, and the maxim of manner. Some of the violations are seen in the following conversation.

1. A : "Jadi yang menentukan anggaran ini
jatuh ke proyek, taruhlah proyek di
Hambalang atau proyek di Medan sana,
calo?"(1)
'So the one who decided this budget
went to a project, let say project in
Hambalang or project in Medan, is a
broker?'
: 'Ya, saya kira calo yang-yang-yang
bermain kemudian bertautan dengan
Orang-orang yang ada di DPR (2).
'Yes, I think brokers who-who-who was
played then linked with people in DPR'

(DTILC-80-6)

The context of the conversation: This conversation was happened between representatives of NGO and the Indonesian Budget Control. The topics which were discussed where corruption budget in parliament. In this conversation, A asked about budgetary conditions that occurred in the parliament. A expects B can provide clear information because $\mathrm{B}$ has been doing the observation and tracking of the budget decision process in parliament.

B's answer as shown in the utterance (2) is a form of implicatures since it violated the maxim of quantity. In answering questions from $\mathrm{A}$, the speaker should give a simple answer either yes or no. However, the speaker provides additional information to confirm the answer. Furthermore, based on the context, the implication which occurred is that there are brokers inside and outside the parliament. A violation of maxim of quantity is done to give firmness that the speaker has good reason to answer yes.

Meanwhile, the word bermain implies a different meaning with real meaning or playing in English. The word bermain literally means 'to do something for fun' (KBBI, 2008, p. 858). However, in the context of this conversation, the word bermain implies budget corruption in 
parliament because the context of the speaker and hearer are projects that will be executed by the government. The speaker added explanation to assert that he agreed with what was inferred by the hearer in question.

Calo or 'broker' is a person who became an intermediary and provide its services to arrange things based on wages, can be referred to an intermediary or broker (KBBI, 2008, p. 238). In his statement, the speaker implies the existence of people who are playing with the budget mediates between parliament and the project holder. This is related to the context of the conversation between the speaker and hearer above. Thus, the statement is a form of speaker's agreements that aimed at affirmation of the statement.

Meanwhile, maxim of quality violation is seen in the following conversation.

2. A $\quad$ : "Jadi LSM nya bikin-bikin data?" (1)
'So, the NGO has created the data?'
: "Bisa jadi mendapat informasi yang
salah atau ngarang pak" (2)
'It could be misinformation or trump
up, sir'

(DTILC-80-38)

Context: This conversation happened between host of ILC with a House of Representatives Budget Committee. In the previous conversation with A, B criticized the participants in the ILC dialogue who has accused some mistakes in the budget commitee without any proofs. Then, B said that NGO which has the data about corruption budgets do not have valid information.

B's utterance is included into implicature utterance bocause it violated the maxim of quality where the speaker was not sure on what he declared by stating "it could be" at the beginning of his statement. The use of "could be" in the beginning of a sentence indicates the implications of fuzzy meaning in speaker's utterance. Meanwhile, the word ngarang is derived from the word karang or mengarang in Bahasa which means something that is not true; fetched (KBBI, 2008, p. 624).

So, the making-up words in a conversation implies an activity which is made-up so the speaker wanted to imply that the results cannot be trusted because the NGO is not necessarily true. The implication is the speaker considered that the results of research from NGO stated that corruption which happened in the budget committee is not something to be trusted, but the speaker was also not sure because he had no evidence related to his statement. The speaker actually wanted to influence the hearer and the community to protect the institution's self-image and the negative result of research which conducted by the NGO. Therefore speaker has violated maxim of quality in order to maintain a good image of the institution.

In addition to the form of implicature that occurs due to the violation of cooperative principle, in this analysis the writer also found some forms of implicatures that occur because of the conventional meaning of the words which used by speakers when they are speaking. It means that the form of implicature is not only appeared because of the cooperative principle violation, but also occurred because of meaning convention contained in an utterance. This kind of form is shown in the following statements.

3. : : "Kalau bicara gempa sebetulnya yang lebih dahsyat waktu kasus cicak buaya ya, dibandingkan dengan ini (4)...”

'Talking about earthquake, actually the most powerful one was cicak-buaya case compared to this...'

(DTILC-78-19)

Context: This speech uttered by a member of the State Audit Agency (BPK). In the conversation, the emcee asked the speaker's opinion about the meeting which mentioned by the suspected cases of athlete dormitory in mass media that he had met with the leadership of the Corruption Eradication Commission (KPK) together with one of a party leader. This causes problems because the leader of the Corruption Eradication Commission (KPK) should not have held a private meeting with political parties.

In his statement, the speaker mentioned that the issues raised in the Corruption Eradication Commission is not affected by the case of athlete dormitory, but relates to the case of cicak-buaya (lizard-crocodile). Its function is to satirize the opinion that the meeting between leader of KPK and the suspected cause earthquakes. The earthquake which was told by the speaker in the above statement refers to large problems. The meaning of earthquakes or gempa in Bahasa cannot be associated to natural disasters because it refers to the name of a party and KPK. Thus, the meaning of the earthquake in this case corresponds to destruction or a major problem that will come to the

party. 
In addition, in the utterance (4), the speaker also mentioned the term cicak-buaya or lizardcrocodile. The term does not refer to the type of animal, but refers to the events of the feud between KPK and the National Police of Indonesia in 2009. At that time, one of the National Police officials made a statement in a national magazine "... Lah wong cicak kok melawan buaya" which means "Why would a lizard fights against a crocodile" when KPK wanted to investigate some officials of Police relating to a case (Detik Magazine, 2012).

Cicak in this context refers to KPK, while buaya refers to police. Since then, this case has raised polemics in the society and was known as case of cicak vs buaya. The utterance (4) is a significant allusion to the statement of suspected person about his meeting with leader of KPK. The speaker wanted to argue that the statement of suspect is not a problem for KPK because of the feud between KPK and Indonesian National Police is considered more severe. Therefore, the speaker cited that the case of cicak-buaya in his statement as a comparison. Speaker hoped that the dialogue participants and ILC viewers understood that the meaning of cicak-buaya refers to the dispute of KPK and Indonesia National Police because it has the same background knowledge about it.

The forms of implicature in political discourse on ILC are found in the form of declarative and imperative. While, interogative form is not found in this show. It is happened due to the violation of cooperation principles which is stated by Grice. Cooperation principle violations consist of quantity maxim, quality maxim, relevance maxim, and manner maxim. The other forms of implicature also have been found related to conventional meaning of words which are used by speakers in this show. It means that, implicature forms are not only happened because of cooperation principle violation, but also affected by conventional meaning in an utterance.

\section{B. TYPES of IMPLICATURE}

From the analysis of the types of implicature in political discourse on ILC, it is found types of implicatures; conventional implicature, particular conversational implicatures, generalized conversational implicatures, and implicatures of scale. Conventional implicatures is characterized by the convention agreement of speaker and listener in politics such as the names of politicians, corruption cases, personification, and expressions about politics, for example:

4. : "...Yang saya simpulkan adalah karena
Nazaruddin ini adalah bom atom yang bisa
meledak ya..."
'I concluded that because this Nazaruddin is an
atom bomb which can be exploded, right..."

(DTILC-80-50)

Context: This utterance is a statement of a political observer. The topic discussion in that utterance was the case of one of the government party member related to the corruption of athlete dormitory. The speaker stated that members of the party could lead to chaos in the party.

This utterance Is a form of implicature utterance which aimed at allusion to the Democratic Party. In the above utterance, the speaker associated that name with an atomic bomb. The speaker wanted to satirize the conditions of governing party since the discovery of athlete dormitory case involved one member of the party as mentioned by the speaker. Thus, the conventional meaning of the reference in the utterance is a person's name and the word meledak or explodes.

If we examined it literally, the person's name and the word explode cannot be associated to each other because he is a man who could not be exploded. According to KBBI (2008, p. 802) the meaning of meledak is ruptured and wheezed explosion; issue of war; echoed, bells and whistles, laughing; or multiplied. However, based on the context, the word meledak in the utterance (1) implies the meaning as mention. The point is that, the person has been the most potential informant who mentioned a number of names that can affect the condition of his party.

In addition, the speaker associated him as an atomic bomb to insinuate that the name is very dangerous for his party. Based on its definition, the atomic bomb is a bomb explosion which occurred due to the release of atomic energy that is generated by the breakdown of a core of heavy chemical elements with neutrons in a very fast chain reaction (KBBI, 2008, p. 205). The atomic bomb is also known as a destructive weapon, that is why the speaker associated the meaning of this name as a destructive weapon that could destroy his party in a very quick time if he mentioned a number of names who are related to the athlete's dormitory

case. 
Types of generalized conversational implicature are also found in this show. This type of implicature does not require the specific context in discovering implications because the implications of the utterance can be found in a conversation between speaker and hearer. For example:

5. A : "Untuk partai demokrat sendiri ini kabar
baik atau kabar duka?" (1) (hadirin
tertawa)
'For democracy party, this is good news
or sad news?' (the audiences laugh)
B : "Saya kira e:: bukan kabar duka (3)
(hadirin masih tertawa dan bertepuk
tangan) JADI-, saya kira pertanyaan
yang baik Pak Karni, spekulasi seperti
itulah yang muncul dan bergulir
selama tiga bulan terakhir dan ini
(4)..."
'I think, um:: this is not a bad news (the
audiences laugh and clap) SO-, I think
this is a good question Mr. Karni,
that's the speculation which have been
occurred and rolled for the last three
months and this is...'

(DTILC-79-11)

Context: This conversation was happened between host of ILC and Honorary Secretary of the Board of Democratic Party. The topic discussion is the return of suspected cases of athlete dormitory from Colombia who is a member of the party. A asks B about this fact as a representative of the party which is related to this case.

This utterance is included into conversational implicatures because A's questions which gave preference to B between "kabar baik atau kabar $d u k a "$ which means good news or sad news. So the answer that should be given by $\mathrm{B}$ is one of the choices. When B gives the answer "bukan kabar $d u k a "$ which means it is not the sad news, then it implies that the speaker intends to declare it as "good news". The context of implicature in this conversation is found from the question which was said by the listener, it means that it is not required the specific context of implications of speakers.

Furthermore, the particularized conversational implicatures is characterized by a special context that followed the implicature of utterance. This specific context is related to political issues which have been ever or is happening at that time as shown in the following conversation.

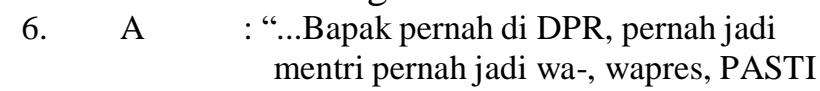

bapak lebih tau dari saya (1) Apa yang terjadi sesungguhnya? (2)"

'....You had been in DPR (parliament), had been a ministry, had been a vivice president, you MUST be know better than me. What's going on actually?'

B

: "Ya itu teori umum saja POWER tends to corrupt (3)

'Yeah that's a general theory POWER tends to corrupt'

(DTILC-80-17)

Context: This conversation was happened between host of ILC with a former vice president of Indonesia who are talking about corruption in parliament. Then, A asks B's experiences in government.

A's question actually is related to what happens in the parliament especially about corruption which is discussed. However, B gave a statement that led to the cause of corruption in a country. The statement of power tends to corrupt derived from the argument of Lord Acton (as cited in Suhardjana, 2010, p. 256), which states "Power tends to corrupt but absolute power corrupts absolutely" which means that people who have power tend to abuse the power especially when the power is absolute then it would be used in a wrong way. The word power which is misused in the argument aimed at the power of a state or government.

Finally, the utterance directs the listener's and audiences' mind to the one in authority such as the government party and its coalition. This is seemed from the emphasis of word power which is showed by speaker. The speakers wanted to insinuate that corruption both in government and parliament has been clearly made by the government in power; it means the insinuation refers to government party and its coalition. The speaker used that term because he feels that he has the same background knowledge with the listeners who also understand about politics and law. Therefore, to look at the implications in the speaker's utterance, it requires a special context on that point so the implied meaning can be seen clearly.

Furthermore, in this ILC show, it is also found the type of scale of implicature which can be seen from the scale value such as, nothing, except, partially, very little, and scale numbers like five years, and other value scale. One of this type of scale of implicature is: 
7. : “...Dan yang saya SEDIH lagi ya, politisi kita ini sedikit sekali yang mau belajar menjadi negarawan SEDIKIT sekali "

'And the thing that makes me SAD, there are less of politicians who want to learn become a statesman only FEW of them'

(DTILC-79-45)

Context: This utteranes is stated by one of public figure and scientists in Indonesia. In a previous conversation, the presenter and speaker talked about the performance of the Corruption Eradication Commission and the condition of the Indonesia. Then, the speaker also gave his views about the behaviour of the politicians today.

Implicature scale marker in this utterance is value scale of sedikit sekali or few. The scale sedikit sekali or few actually implies the value scale of banyak sekali or many. The word negarawan or statesman reflects someone who is thinking about the state of the nation and country condition. So, the purpose of this utterance is the speaker wanted to illustrate that a lot of politicians who only think about their image for political purposes without thinking about the condition of his people. Thus, the scale of few values determines the implications meaning of many in the utterance.

\section{PRAGMATICS MEANING and PRAGMATICS FUNCTION}

Based on data analysis that has been done, the meaning of implicatures in political discourse on the ILC discovered the meaning of criticism, satire, blurring of the meaning, agreement, objection, imaging, and euphemisms. The meaning of criticism which is implied in the utterance which criticized the statement of politician that is not in accordance with the opinion of the speaker. Furthermore, the meaning of satire appears in the utterances which contain taunts, insults, irony and allusions to the listener, politician, and government. Then, the meaning of blurring occurs when the speaker wants to circumvent the possibility of statements that could affect the positive image of himself or his group in public.

Meanwhile, the meaning of agreement was found when the speaker wants to approve the listener, but by providing information that is more or unrelated to the topic of conversation. The meaning of denial implies in the utterance that shows disagreement of speaker to the hearer's statement or statements which are given by others. Furthermore, the meaning of imaging is the meaning which implies a positive image of himself or his group through a statement. The meaning of euphemism of utterances has the purpose of smoothing the meaning of the word which is not good. So, every meaning has intention and factor which affecting the implications of utterances.

Meanwhile, the pragmatic function of implicature in political discourse on ILC is found in assertive function, directive function, expressive function, and commissive function. Assertive function is found in the utterance that aimed to avoiding, affirming, explaining, debating, approving, and refusing. Avoiding function intended to avoid answers that could affect the self-image of speaker or a group, while the affirming functions are found in the utterance that aims to convince the hearer of what is expressed by the speaker.

Furthermore, the explaining function is used to provide the reasons which are explained in the answer or give opinions. Debating functions are found when the speaker wants to argue with the listener by giving reasons of the speaker's denial. Furthermore, the approving functions are contained in the utterances which indicate agreement between speaker and listener. Refusing functions are implied in the speech that showed disagreement of speaker with listener's statement.

Directive function are classified into several types, those are affecting, greeting, and asking. The utterance that aimed to affecting occurs because the speaker wants to form a positive image of himself or his group so that can gain public sympathy. Speaker also uses the implicature utterance to greet listener by using listener positions as the background of what he said. Furthermore, the speaker provides information which implies that the speaker wanted to ask the opinion of listener about political issues that are being discussed.

Then, the expressive function can be divided into several functions, those are satirize, criticize, and grateful. Speakers use implicature that aim at insinuate when they want to tease criticize or deride their hearers, politicians, the government or the current situation at the time. Criticizes function appeared when the speaker wants to denounce the actions or statements of others with his own 
opinion. Speakers also use implicatures to thank the other politicians because they have the same political purpose.

Commissive function could be found when speaker promised indirectly through the utterance. Speakers use implicature to demonstrate the ability or positive image due to certain political goals. Meanwhile, declarative function could not be found in political discourse on ILC event because the speakers do not use any form of utterance that connects between the contents of the speech with indirect reality, so that it cannot be classified into a form implicatures. Some sentences were only found as declarative function in the form of direct utterance.

\section{VALUES}

From the analysis of this research, the values which are found in implicature utterance in political discourse on ILC show consists of political values and moral values. Political values are found in the form of imaging ideological values, power values, values of reluctance, democratic values, and the value of protection. Imaging ideological values are characterized by the use of language that shows the advantages of self or group such as pro-people or anti-corruption vocabularies. Meanwhile, the value of power is characterized by the vocabulary that indicates a shortage of political opponents and the superiority or groups.

Value of reluctance is characterized by utterance that shows the defence of another person in a political group with the same understanding. Furthermore, democratic values are used to indicate the recognition of the rights and obligations of others. Protection value is contained in an utterance which wants to protect the selfimage or group of statements hearer or others that could reduce public sympathy towards him. Meanwhile, the moral values are found in political discourse because it is characterized by the counsel which is related political issues, while those overall values are influenced by political goals to be conveyed to the public speakers or other politicians.

\section{CONCLUSION}

Based on the analysis which has performed in this study, it can be concluded that a form of implicatures in political discourse at the ILC was found because of the violation of the principle of cooperation. The forms of utterances that were found in the dialogue of the show consist of declarative and negative form. The violated towards the principle of cooperation consists of maxim of quantity violation, violation of quality maxim, maxim of relevance violation, and the maxim of manner violation. In addition, the form of implicatures also arisen because the conventional meaning of the words are used by speakers. This is the reason why interogative forms are not arisen in the dialogue. Furthermore, from the analysis of the type of implicature, it is found that the type of implicature in political discourse on ILC show consists of types of conventional implicature, particularized conversational implicatures, generalized conversational implicatures and implicatures of scale.

In the political discourse on ILC show, it is found that there are seven types of meaning that is appeared on utterances that imply criticism, satire, blurring meaning of the agreement, rebuttal, imaging, and euphemisms. Meanwhile, in this study also has been found four implicatures function in political discourse on ILC show, they are the function of assertive, directive, expressive, and commissive. In addition, the use of these implicatures refers to some value that is the value of political and moral values.

Thus, it can be concluded that the implicature utterances have been one of the strategies which is used in political discourse on the ILC show. By using implicature, politicians can affect the mind of hearer or the people who watch the show without having to express it openly. The use of implicature intended to convey some political purposes implicitly through mass media to the public. Therefore, implicatures become one of the strategies that are used in politics to acquire, operate, or maintain power as it has been described by experts earlier.

\section{REFERENCES}

[1] Cutting, J. (2002). Pragmatics and Discourse. London \& New York: Routledge

[2] Darma, Y. A. (2009). Analisis Wacana Kritis. Bandung: Yrama Widya

[3] Departemen Pendidikan Nasional. (2008). Kamus Besar Bahasa Indonesia. Jakarta: Gramedia Pustaka Utama

[4] Gazdar, G. (1979). Pragmatics Implicature, Presupposition, and Logical Form. New York: Academic Press 
[5] Grice, H. P. (1989). "Logic and Conversation" in Studien in The Way Words (22-40). Cambridge, MA: Harvard University Press. Retrieved from http://www.ucl.ac.uk/ls/studypacks/Grice-Logic.pdf (1 April 2012)

[6] Kridalaksana, H. (2008). Kamus Linguistik. Jakarta: PT Gramedia Pustaka Utama.

[7] Leech, G. (1993). Prinsip-prinsip Pragmatik. Jakarta: Universitas Indonesia

[8] Levinson, S. C. (1983). Pragmatics. Cambridge: Cambridge University Press

[9] Lubis, A. H. H. (1994). Analisis Wacana Pragmatik. Bandung: Angkasa

[10] Majalah Detik. "Cicak vs Buaya Jilid 1". Edition 13-19 August 2012

[11] Mulyana. (2001). "Implikatur dalam Kajian Pragmatik". DIKSI 8(19): 53-63. Retrieved from http://ebookbrowse.com/implikaturdalam-kajian-pragmatik-pdf-d404739173 (18 April 2012)
[12] Odgen, C.K \& Richards, I.A. (1985). The Meaning of Meaning. London: ARK Paperbacks

[13] Oktavianus. (2004). Analisis Wacana Teori dan Aplikasi. Padang: Fakultas Sastra Universitas Andalas.

[14] -----------. (2006). Analisis Wacana Lintas Bahasa. Padang: Andalas University Press

[15] Schiffrin, D, Tannen, D., \& Hamilton H. E. (2003). The Handbook of Discourse Analysis. Oxford: Blackwell Publishing

[16] Sudaryanto. (1993). Metode dan Aneka Teknik Analisi Bahasa. Yogyakarta: Duta Wacana University Press

[17] Thomas, J. (1995). Meaning in Interaction An Introduction Pragmatics. London: Longman

[18] Wijana, I. D. P. (1996). Dasar-dasar Pragmatik. Yogyakarta: Andi

[19] Yule, G. (1996). Pragmatics. New York: Oxford University Press 